
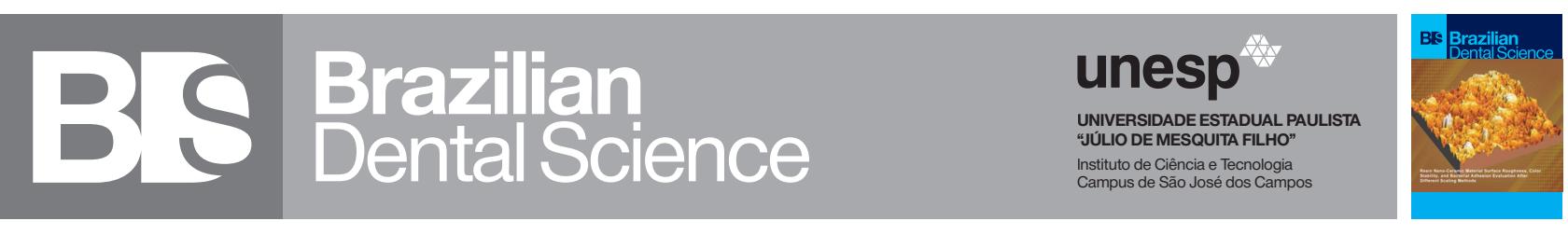

\title{
Resin Nano-Ceramic Material Surface Roughness, Color Stability, and Bacterial Adhesion Evaluation After Different Scaling Methods
}

\author{
Rugosidade superficial, estabilidade de cor e adesão bacteriana de resina nano-cerâmica após diferentes métodos de raspagem
}

Engy Adel Ahmed FARAG ${ }^{1}$, Tarek Salah MORSI ${ }^{2}$, Marwa Mohamed WAHSH ${ }^{2}$, Amr Saleh EL-ETREBY ${ }^{2}$

1 - The British University in Egypt, Fixed Prosthodontics,Faculty of Dentistry,Cairo,Egypt

2 - Ain Shams University,Fixed Prosthodontics, Faculty of Dentistry, Cairo,Egypt.

\section{ABSTRACT}

Objective: TThe study evaluated in vitro the changes in roughness, color stability, and bacterial count of a CAD/ CAM Resin Nano-Ceramic material surface treated by various scaling procedures. Material and Methods: 70 disks (5mm diameter, $0.5 \mathrm{~mm}$ thickness) of Resin NanoCeramic (Lava ${ }^{\mathrm{T}}$ Ultimate, 3M, ESPE) material were cemented in standardized cavities prepared in bovine teeth. A custom-made scaling apparatus of a double pan balance was used for different scaling methods, simulating standard clinical conditions. The specimens were assigned to three main groups: no scaling $(C)$, ultrasonic scaling (U), and manual scaling (M). Each group was then divided into three subgroups according to scaling tip material; stainless steel tip (St), plastic tip (P), and titanium tip (Ti). The surface texture was analyzed quantitatively and qualitatively with a tactile profilometer and atomic force microscopy. A spectrophotometer was used for color measurement. Streptococcus mutans were counted in a colony counter. All the data were tabulated and statistically analyzed. Results: Two-way ANOVA was used to study the effect while One-way ANOVA was performed to compare between study groups. The significance level was set at $\mathrm{p} \leq 0.05$. The ultrasonic titanium tip(UTi) revealed the significant highest mean value of alterations ( $p<0.001$ ). The integrity of the material surface was altered in the form of deep scratches on the ultrasonically scaled surfaces and numerous smaller scratches on the hand-scaled surfaces. Conclusion: The plastic instrument would appear to be the instrument of choice during a routine maintenance procedure for Resin Nano-Ceramic materials.

\section{KEYWORDS}

Bacterial biofilm; Dental ceramics; Color stability; Scaling; Surface roughness.

\section{RESUMO}

Objetivo: Este estudo avaliou in vitro as alterações na rugosidade, estabilidade de cor e quantidade de bactérias da superfície de uma resina nano-cerâmica produzida em CAD/ CAM tratada por diferentes procedimentos de raspagem. Material e Métodos: 70 discos ( $5 \mathrm{~mm}$ diâmetro, 0,5 espessura) de resina nano-cerâmica (Lava ${ }^{\mathrm{TM}}$ Ultimate, 3M, ESPE) foram cimentadas em cavidades padronizadas preparadas em dentes bovinos. Um aparato customizado de raspagem com pratos duplos de balança foram usados para os diferentes métodos de raspagem, simulando uma condição clínica padronizada. Os espécimes foram distribuídos em três principais grupos: Sem raspagem (C), raspagem ultrassônica (U) e raspagem manual (M). Cada grupo foi dividido em três subgrupos de acordo com a ponta do material de raspagem; ponta de aço inoxidável (St), ponta plástica $(\mathrm{P})$, ponta de titânio (Ti). A textura da superfície foi analisada qualitativamente e quantitativamente por um perfilômetro tátil e microscopia de força atômica. Um espectrofotometro foi usado para a mensuração da cor. Estreptococos mutans foram contados em um contador de colônias. Todos os dados foram tabulados e analisados estatisticamente. Resultados: Anova dois fatores foi utilizado para estudar os efeitos, enquanto ANOVA um fator foi utilizado para comparar os grupos experimentais. O nível de significância foi estabelecido em $\mathrm{p} \leq 0,05$. A ponta de ultrassom de titânio (UTi) revelou o valor significante mais alto de alterações $(\mathrm{p}<$ 0,001). A integridade da superfície d matérias foi alterada na forma ranhuras profundas, nas superfícies raspada por ultrassom e numerosas ranhuras menores nas superfícies raspadas à mão. Conclusão: $O$ instrumento plástico poderia apresentar-se como um instrumento de escolha durante o pocedimento de manutenção routineira para materiais de resina nano-ceramica.

\section{PALAVRAS-CHAVE}

Biofilme bacteriano; Cerâmica dental; Raspagem; Rugosidade superficial. 


\section{INTRODUCTION}

E xpanded demand for esthetics in dentistry has led to the increased usage of ceramic and tooth-colored composite resin restorations. Dental materials have evolved with the arrival of nano-technological research focusing on the manufacturing and application of nanoparticles with remarkable structural characteristics. Resinbased dental materials containing nanoparticles currently have the highest feasibility for clinical use [1].

Lava Ultimate, is a resin nano-ceramic material among the most widely used CAD/CAM products. The nanotechnology in Lava Ultimate restorative is coupled with resin technology to gain a combination of strength and esthetics beyond what current feldspathic ceramics or composite blocks give [2]. It consists of $80 \%$ (by weight) nano-ceramic particles of zirconia, silica, and zirconia/silica cluster agglomerates which are bound in the resin matrix. The chemical composition of the material and its resin content impacts the way the material reacts to roughness [3].

Plaque control is important for the prevention of inflammatory periodontal disease. The goals of scaling are to disrupt the dental biofilm. Hand instruments and ultrasonic scalers have shown to be effective for the removal of plaque and treatment and prevention of gingivitis and periodontitis [4,5]. Instruments used to carry out this operation are made of materials that are hard and rigid enough to remove calculus and plaque from the surfaces of the natural tooth and flexible enough to maintain contact with those surfaces while being manipulated by the clinician [6].

Several researches have determined textural alterations of restorations and root surfaces after periodontal scaling $[7,8]$. It may lead to damage of porcelain veneers and various restorations and may cause alterations in esthetic appearance or increase plaque accumulation potential. Surface roughness can be measured up to nanoscale by quantitative methods, as profilometry. Currently, atomic force microscopy (AFM) has been largely used in dentistry to study the characteristics of different materials. Surface topography is three-dimensional. The measurement of 3-D surface topography can represent the natural characteristics of a surface [9].

The esthetic appearance and durability of tooth-colored restorations depend closely on a smooth surface texture that is of great importance for restorations. Together with the color and composition of a material, the surface condition affects the optical appearance of a restoration, which should not be underestimated [10]. Also, roughness influences bacterial colonization and enhances the rate of plaque formation. The biofilm formation and bacterial accumulation on dental materials may lead to gingival inflammation and secondary caries development [11].

The CAD/CAM nanoceramic blocks are more easily machinable than ceramic blocks. Still, when compared to ceramic blocks intended for the same application, the Lava ultimate nanoceramic blocks are questionable concerning their mechanical properties, wear resistance, and biocompatibility. Therefore, there are major concerns regarding to their long-term performance. Additionally, there is little information available regarding their color stability and surface roughness.

The present study aimed to assess surface texture, color stability alterations, and bacterial accumulations on the experimented resin nano-ceramic restorative material surface after periodontal prophylactic procedures. The null hypothesis of the present study was that the various scaling procedures would not produce changes in the roughness, color, and bacterial accumulation of resin nano ceramic material surfaces. 


\section{MATERIAL AND METHODS}

\section{Preparation of bovine teeth:}

Seventy freshly extracted, non-carious bovine central incisors teeth with the same size and thickness were collected. Soft tissues were removed manually, and the teeth were cleaned with a pumice and water slurry. The teeth were amputated $1 / 3$ gingivally to cementoenamel Junction (CEJ) to remove the roots from the teeth, using a diamond disc (Diamond disc, Fway Industrial Co.,China) with a copious amount of water coolant. The teeth were mounted with a white stone in a polypropylene plastic tube with an internal diameter of $2 \mathrm{~cm}$ and a length of 1.5 $\mathrm{cm}$.

Before the study was taken, five extra bovine anterior teeth were collected, cleaned, and checked for the thickness of enamel. The crowns of the teeth were sectioned horizontally in inciso-cervical direction. The enamel thickness was measured using a digital caliper. It was found to be of average $1.9 \mathrm{~mm}$.

To flatten an area of the enamel surface, the labial surface was smoothed back and forth in inciso-cervical direction (5 strokes) using the side of a flat-ended cylindrical diamond stone ( Diamond stone, Meisinger, Germany ) under running water then was polished with sof-lex discs (Medium Sof-Lex Polishing Discs, 3M) to obtain standardized flat enamel surfaces. The teeth were randomly allocated into three main groups based on the scaling method; No scaling Control (C) group of 10 samples, Ultrasonic scaling group (U) of 30 samples, and Manual Scaling group (M) of 30 samples.

\section{Cavity preparation in the bovine teeth:}

To unify cavity dimensions, a diamond wheel stone (Dian Fong Industrial Co., Ltd, China) $5 \mathrm{~mm}$ in diameter was mounted into a contraangle handpiece. Then, a specially designed depth limiter hollow metal ring of internal diameter 6 $\mathrm{mm}$ and length of $1 \mathrm{~cm}$ was attached to the head of the handpiece by glue (Amir Alpha, Egypt), acting as a stopper for limiting the depth of drilling. To adjust the exposed drilling and cutting part of the stone, a specially designed calibrating metal tool of internal depth of $0.5 \mathrm{~mm}$ and 0.5 $\mathrm{mm}$ diameter was used. It was placed over the cutting end of the wheel stone and rested over the depth limiter. A cavity of $0.5 \mathrm{~mm}$ depth and $5 \mathrm{~mm}$ in diameter was then created in the center of the flattened area. The depth of the cavity was checked with the digital caliper.

Preparation of resin nano ceramic discs and cementation:

CAD/CAM resin Nanoceramic blocks (Lava ultimate, 3M ESPE, Seefeld, Germany) were used. The blocks used were of size 12 and the shade was A3.5 and Low Translucency (LT) based on the VITAPAN Classical Shade Guide. The nanoceramic blocks were ground into cylinders with continuous instillation using a milling machine and were then checked for 5 $\mathrm{mm}$ diameter using a caliper. The cylinders were cut into discs of $0.5 \mathrm{~mm}$ thickness, simulating laminate veneers thickness, using a linear precision saw (IsoMet 4000, precision cutter, Buehler, USA). The inner surface of each disc was pre-treated per manufacturer specifications. The cement (Variolink II, Ivoclar Vivadent) was applied to the prepared cavities. The discs were then carefully held and placed inside the cavities. Subsequently, excess cement was removed with a micro brush. Light-curing was performed with a LED curing unit (Demi, Kerr, Middleton, WI, USA). After cementation of the discs, the exposed outer surfaces were finished according to the manufacturer's recommendations.

\section{Scaling apparatus and scaling procedures:}

A scaling apparatus was specially designed for the experiment. A diagram illustrating the apparatus is represented (Figure 1). It consisted of a gearbox to reduce the speed of the motor to 1 cycle per second, with a crankshaft and a 
connecting rod attached to a slider to change the rotational movement into linear movement. The samples were mounted onto a double pan balance using a screwed mold. For the ultrasonic scaling group (U), the 30 samples were subdivided equally into 3 subgroups according to tip material; stainless steel tip ( NSK G3 ), plastic tip (NSK Maintenance plastic V-Tip), and titanium tip (Woodpecker Titanium Nitride Scaling Tip). The ultrasonic scaler handpiece (Satelec Ultrasonic Scaler, USA) was used throughout the experiment at an intermediate power setting (level 5 of 14 grades). The scaling tips were angled at 90 degrees relative to the surface of the samples (Figure 2). A constant force of $30 \mathrm{~g}$ authorized by the Egyptian Assay \& Weights Administration (E) was applied to the ultrasonic scaler tip by the vertical movement of a counterweighed balance. A standardized $5 \mathrm{~mm}$ horizontal movement and three consecutive cycles of 20 seconds each of the ultrasonic hand piece at a speed of $2 \mathrm{~Hz}$ was achieved and operated by the control box while a timer and coolant were being used [12].

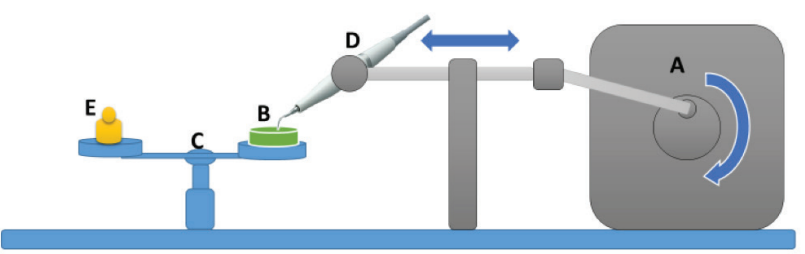

Figure 1 - Diagram showing the Scaling Apparatus Parts: AGear Box; B-A sample mounted on the apparatus; C-DoublePan Balance; D-Ultrasonic Scaler Hand Piece; E-Constant Weight.

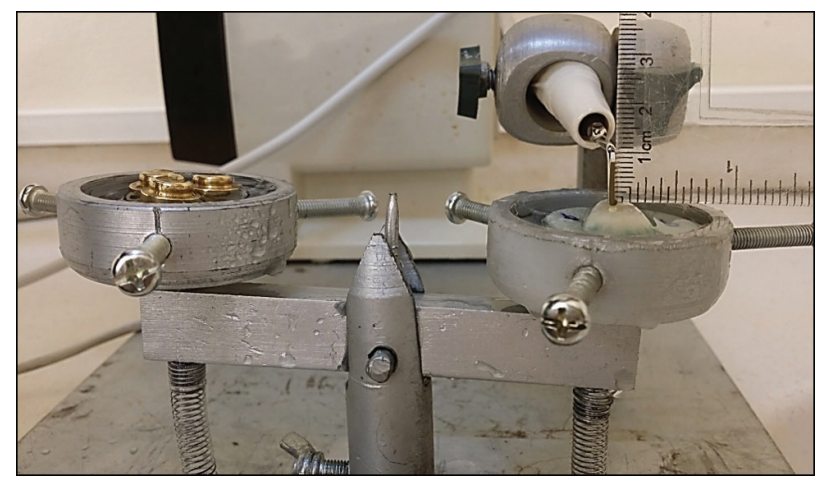

Figure 2 - Ultrasonic scaling tips checked for being angled at 90 degrees relative to the surface of the samples.
While for manual scaling group (M), the 30 samples were subdivided equally into 3 subgroups according to tip material; stainless steel curette (Gracey No. 7/8 Hu-Friedy, Chicago), plastic scaler (Implacare Oral Maintenance H6/7, HuFriedy,Chicago) and titanium curette (Universal Curette, TI 23 AS, Deppeler SA,Rolle, Switzerland). Each instrument was fixed in an arm with weights to produce loads of $5.0 \mathrm{~N}$ ( 0.5 Kilograms). The hand instruments were attached with the tip engaged at a 15-degree angle to the specimen while five even strokes were made. The water-cooling system was activated while scaling [13].

\section{Surface Roughness testing before and after scaling:}

The surface roughness of the 70 specimens was measured before and after scaling. The surface roughness was measured from the area of the cemented Lava ultimate discs of samples. This was first done using a tactile profilometer (TR220 Portable Roughness Tester, Innovatest,Germany) with a $0.25-\mathrm{mm}$ cutoff length value and the cutoff number was 1 . Three measurements were made on each specimen. A mean surface roughness (Ra) was determined for each specimen to describe the overall roughness of the surface. After, experimental measurements of 3D surface topography and roughness parameters were obtained using the Atomic Force Microscopy (Thermomicroscope and AutoProbe CP-Research Probe Head).

\section{Color Measurement before and after scaling and staining:}

An intraoral spectrophotometer (VITA Easy shade Advance 4.05, VITA Zahnfabrik, Bad Sackingen, Germany) was used for color measuring before scaling and staining, for the 70 samples. The shade-matching device was operated according to the manufacturer's instructions. The measurement results were shown as VITA classical, VITA system 3D-MASTER shades, and further data of the three-coordinate representation of color (CIE L*a*b*). All seventy samples were then immersed in the coffee solution (Nescafe, Nestle,Switzerland) that was prepared according to the manufacturer's 
instructions. Specimens were left in this solution until the solution temperature reached $37^{\circ} \mathrm{C}$, and then they were put into an incubator (Model B 28, BINDER GmbH, USA). This process was repeated every 48 hours for 2 weeks. Mean values of $L^{*}$, a*, and $\mathrm{b}^{*}$ were saved. The total color change $(\Delta \mathrm{E})$ was calculated for each sample. Color differences $(\Delta \mathrm{E})$ were calculated according to the formula $\Delta \mathrm{E} 2-1=([\Delta \mathrm{L}] 2+[\Delta \mathrm{a}] 2+[\Delta \mathrm{b}] 2) 1 / 2$.

\section{Bacterial Accumulation Testing:}

Bacterial accumulation testing was done for the control group and ultrasonic and manual groups after scaling. After isolation of Streptococcus mutans, a standard suspension of Streptococcus mutans containing 106 cells/ $\mathrm{ml}$ was obtained. Finally, biofilm adhesion was performed in an aseptic environment. Colonies of Streptococcus mutans were counted in a colony counter and mean values of colony forming units were obtained (CFU/ml) [14].

\section{RESULTS}

Data were presented as mean, median, standard deviation (SD), minimum, maximum, and 95\% Confidence Interval for the mean values. Two-way Analysis of Variance (ANOVA) was used to study the effect of scaling method, tip material, and their interaction on roughness, color change, and bacterial counts. For nonparametric data, Kruskal-Wallis test was used to compare the different study groups. MannWhitney test with Bonferroni correction was used for pair-wise comparisons when Kruskal-Wallis test is significant.

For parametric data, One-way ANOVA was performed to compare the different study groups. Tukey's post-hoc test was used for pair-wise comparisons when ANOVA test is significant. Dunnett's test was used to compare the control group with scaling method groups ( $\mathrm{p} \leq 0.05)$.

\section{Statistical Analysis}

\section{A. Surface roughness (Ra)}

A two-way ANOVA test showed that the scaling method and tip material had a significant effect on surface roughness ( $\mathrm{Ra}$ ). Mann-Whitney test showed that the ultrasonic method had a statistically significant higher mean value of surface roughness compared to the manual method. Kruskal-Wallis test showed that in the ultrasonic group, Titanium tip (UP) yielded the statistically significant highest mean value of surface roughness while in the manual group, the plastic tip (MP) showed the statistically significant lowest mean. Table I shows the mean values and standard deviations values of surface roughness of different scaling methods in comparison to baseline values. All baseline mean values of surface roughness showed statistically significant mean values lower than that following scaling with different scaling methods.

Table I - The mean, standard deviation (SD), and P-values for comparison between surface roughness $(\mu \mathrm{m})$ at baseline and after different scaling methods

\begin{tabular}{ccccccc|}
$\begin{array}{c}\text { Tip } \\
\text { material }\end{array}$ & Time & \multicolumn{2}{c}{ Baseline } & \multicolumn{2}{c|}{ After } & P- \\
& & Mean & SD & Mean & SD & value \\
$\begin{array}{c}\text { Ultrasonic } \\
\text { (U) }\end{array}$ & $\begin{array}{c}\text { Stainless } \\
\text { steel(St) }\end{array}$ & 0.1663 & 0.0498 & 0.7626 & 0.0657 & $<0.001^{*}$ \\
& Plastic(P) & 0.1655 & 0.0565 & 0.4885 & 0.0576 & $<0.001^{*}$ \\
& Titanium(Ti) & 0.1699 & 0.0368 & 1.2088 & 0.1733 & $<0.001^{*}$ \\
\hline $\begin{array}{c}\text { Manual } \\
\text { (M) }\end{array}$ & $\begin{array}{c}\text { Stainless steel } \\
\text { (St) }\end{array}$ & 0.1582 & 0.0515 & 0.5898 & 0.0537 & $<0.001^{*}$ \\
& stSt. & 0.1712 & 0.0372 & 0.2727 & 0.0422 & $<0.001^{*}$ \\
& Plastic(P) & 0.1687 & 0.0597 & 0.8809 & 0.0864 & $<0.001^{*}$ \\
\hline
\end{tabular}

*: Significant at $p \leq 0.05$

\section{Atomic Force Microscopy Results}

The obtained results of differently scaled surfaces of lava ultimate discs were presented in the form of high-resolution 2D and 3D images. The measurement range on all samples was $50 \times 50 \mu \mathrm{m}$. Surface topography assessment of Resin Nanoceramic material surfaces treated by different ultrasonic-scaling tips revealed multiple projections and valleys, whereas the various hand groups had definite line scratches. The scaling method based on a plastic curette (MP) caused the least alteration of Lava ultimate discs surfaces. (Figures 3,4) showed 2D and 3D topographies, surface roughness images, and average surface roughness ( $\mathrm{Ra}$ ) before and after ultrasonic stainless steel (USt) scaling procedures of lava ultimate discs. 

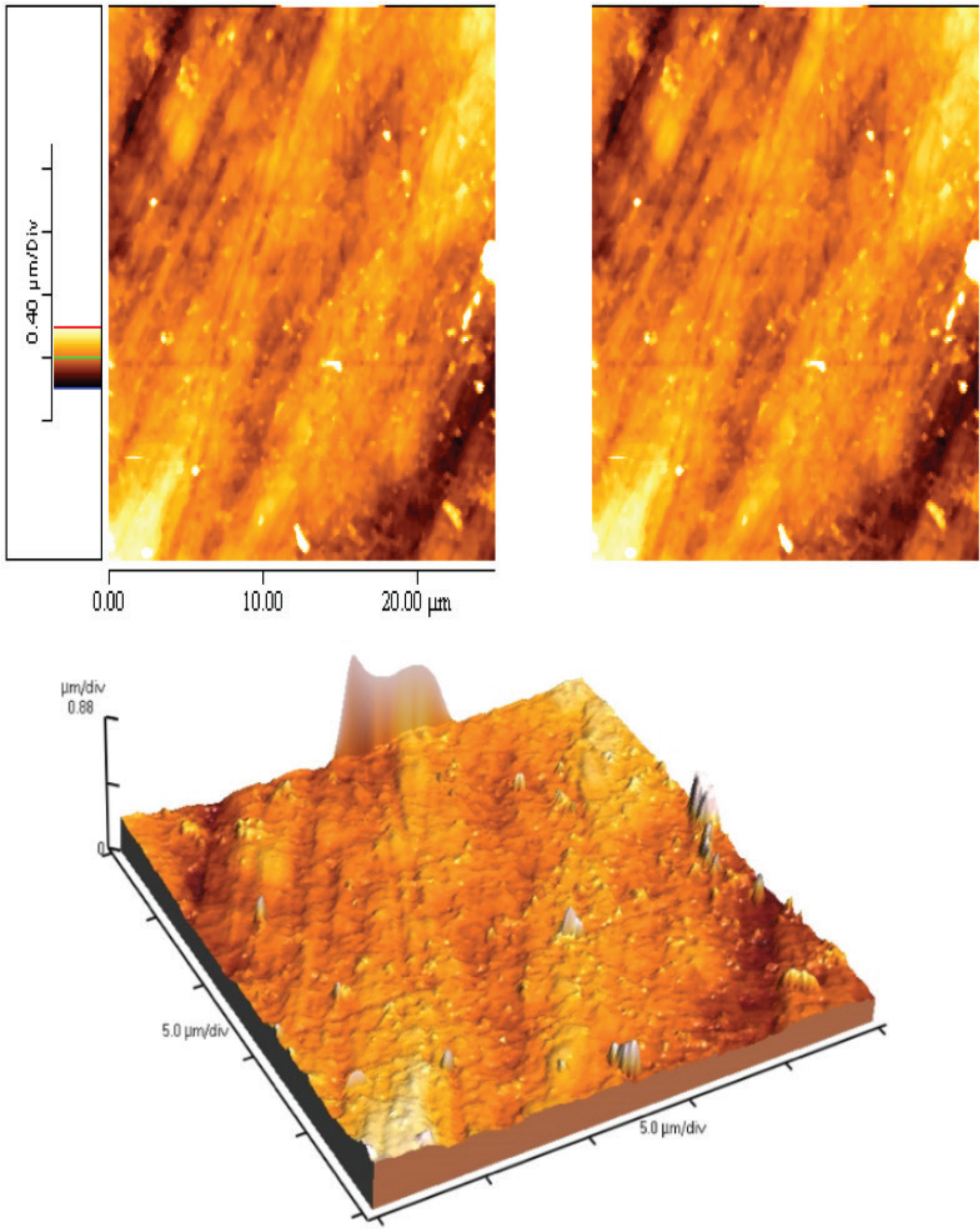

Figure $3-2 \mathrm{D}$ and 3D topography and surface roughness (Ra) of Lava Ultimate before scaling. 

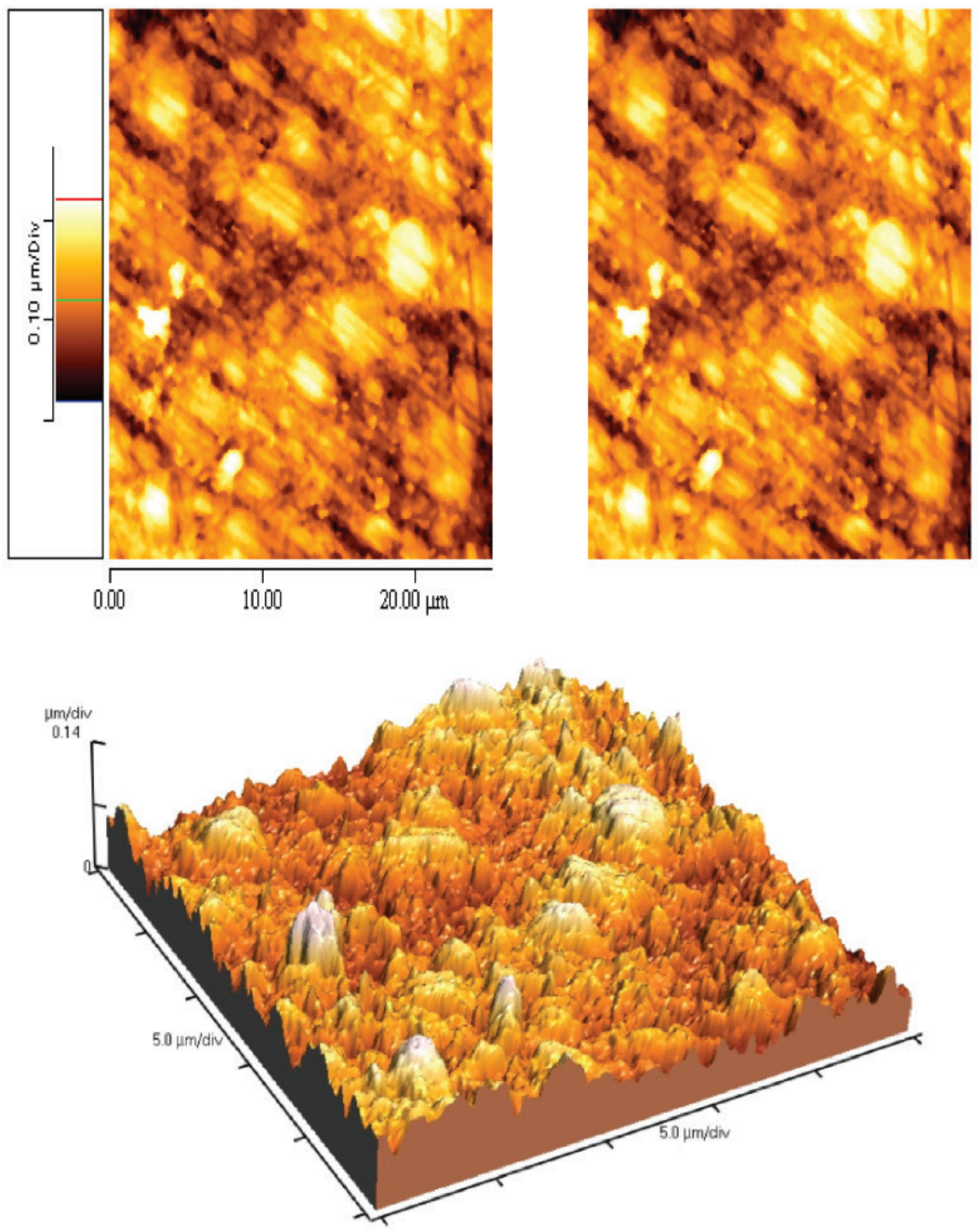

Figure 4 - 2D and 3D topography and roughness of Lava Ultimate sample after using Ultrasonic Stainless Steel tip. 


\section{B. Color changes $(\Delta \mathrm{E})$}

Descriptive statistics of $(\Delta \mathrm{E})$ values are presented in Table II. Two-way ANOVA test showed that the scaling method, tip material, and their interaction had a significant effect on color change. Within each tip material, Kruskal-Wallis test showed that the scaling methods had statistically significant different $\Delta \mathrm{E}$ mean values. The ultrasonic method (U) had the significantly highest $\Delta \mathrm{E}$ mean values while the control group (C) showed the statistically significant lowest mean $(\Delta \mathrm{E})$. The significantly highest to lowest means are as follows: Ultrasonic Titanium (UTi) > Manual Titanium (MTi) > Ultrasonic Stainless Steel (USt) > Manual Stainless Steel (MSt) > Ultrasonic Plastic (UP) > Manual Plastic (MP).

Table II - Descriptive statistics of Color change $(\Delta \mathrm{E})$ values

\begin{tabular}{|c|c|c|c|c|c|c|c|c|}
\hline \multirow[t]{2}{*}{$\begin{array}{l}\text { Scaling } \\
\text { method }\end{array}$} & \multirow{2}{*}{$\begin{array}{l}\text { Tip } \\
\text { material } \\
\text { ntrol }\end{array}$} & \multirow{2}{*}{$\begin{array}{l}\text { Mean } \\
2.94\end{array}$} & \multirow{2}{*}{$\begin{array}{l}\text { SD } \\
0.07\end{array}$} & \multirow{2}{*}{$\begin{array}{l}\text { Me- } \\
\text { dian } \\
2.92\end{array}$} & \multirow{2}{*}{$\begin{array}{l}\text { Mini- } \\
\text { mum }\end{array}$} & \multirow{2}{*}{$\begin{array}{c}\begin{array}{c}\text { Maxi- } \\
\text { mum }\end{array} \\
3.09\end{array}$} & \multicolumn{2}{|c|}{$\begin{array}{l}\text { 95\% Cl } \\
\text { Lower Upper } \\
\text { bound bound }\end{array}$} \\
\hline & & & & & & & 2.90 & 2.99 \\
\hline \multirow{3}{*}{$\begin{array}{l}\text { Ultrasonic } \\
\text { (U) }\end{array}$} & $\begin{array}{l}\text { Stainless steel } \\
\text { (St) } \\
\text { st St. }\end{array}$ & 3.71 & 0.06 & 3.73 & 3.58 & 3.80 & 3.67 & 3.76 \\
\hline & Plastic(P) & 3.33 & 0.06 & 3.34 & 3.21 & 3.43 & 3.28 & 3.37 \\
\hline & Titanium(Ti) & 4.55 & 0.35 & 4.48 & 3.98 & 5.24 & 4.30 & 4.80 \\
\hline \multirow{3}{*}{$\begin{array}{l}\text { Manual } \\
\text { (M) }\end{array}$} & $\begin{array}{l}\text { Stainless steel } \\
\text { (St) }\end{array}$ & 3.49 & 0.11 & 3.50 & 3.33 & 3.63 & 3.41 & 3.56 \\
\hline & Plastic(P) & 3.12 & 0.04 & 3.10 & 3.09 & 3.20 & 3.09 & 3.15 \\
\hline & Titanium(Ti) & 3.89 & 0.20 & 3.83 & 3.76 & 4.44 & 3.74 & 4.03 \\
\hline
\end{tabular}

C-Bacterial counts

Two-way ANOVA test showed that the scaling method and tip material had a significant effect on the bacterial count. The interaction between the two variables (scaling method $\mathrm{x}$ tip material) had no significant effect on the bacterial count. Since the interaction between the variables is not statistically significant, so the variables are independent of each other.

Meanwhile, within each scaling method, titanium tips (Ti) showed the statistically significantly highest mean; while the plastic tips (P) showed the statistically significantly lowest mean (Table III). The significantly highest to lowest means are as follows: Ultrasonic Titanium (UTi) $>$ Manual Titanium (MTi) $>$ Ultrasonic Stainless Steel (USt) $>$ Manual Stainless Steel (MSt) > Ultrasonic Plastic (UP) $>$ Manual Plastic (MP).

Table III - The mean, standard deviation (SD), and P-values for comparison between bacterial counts $(\mathrm{CFU} / \mathrm{mL})$ of different tip materials

\begin{tabular}{|ccccccccc|}
\hline $\begin{array}{c}\text { Scaling } \\
\text { method }\end{array}$ & \multicolumn{2}{c}{$\begin{array}{c}\text { Stainless } \\
\text { steel(St) }\end{array}$} & \multicolumn{3}{c|}{ Plastic(P) } & \multicolumn{2}{c|}{ Titanium(T) } & p- \\
& Mean & SD & Mean & SD & Mean & SD & value \\
\hline Ultrasonic(U) & 186.90 & 16.51 & 111.30 & 12.66 & 283.40 & 17.04 & $<0.001$ \\
\hline Manual(M) & 146.90 & 16.14 & 69.30 & 11.57 & 223.50 & 23.89 & $<0.001$ \\
\hline Control(C) & 41.90 & 7.96 & 41.90 & 7.96 & 41.90 & 7.96 & -- \\
*: Significant at $p \leq 0.05$ & & & & & \\
\hline
\end{tabular}

\section{DISCUSSION}

The results support the rejection of the null hypothesis of this study because the various scaling procedures produced significant changes in the roughness, color, and bacterial accumulation of the examined resin Nanoceramic laminate veneer surfaces.

One of the fundamental etiological factors of periodontal disease is the development and maturation of biofilm. The vital target of prevention and/or treatment in periodontitis is the periodic removal of plaque and calcified deposits from teeth and restorations. This procedure may inadvertently influence not only dental tissues but also the restorative materials [15].

Lava ultimate restorative system is claimed to overcome many of the drawbacks associated with traditional dental ceramics by combining resin and Nano-technologies. This polymer-infiltrated ceramic network material has a microstructure close to the natural tooth 
and has mechanical properties that surrender between those of porcelains and resin composites. This material is considered a good choice for ultrathin veneers.

Routine periodontal prophylactic procedures can lead to damage of laminate veneer restorations over time and cause changes in their biomechanical and esthetic appearance such as the increase in surface roughness leading to plaque accumulation. Further investigations of the periodontal instrumentation effect and limitation of the adverse effects of periodontal prophylactic procedures on polished resin Nano ceramic restorations were needed.

A customized scaling apparatus was designed for the study, which allowed scaling at consistent stroke speed and delivering uniform force and uniform unidirectional motion to the samples, standardizing the conditions and helping in comparison of specimens.

The 15-day staining test period was selected because most of the staining occurs after 1 week of immersion in coffee, and the following week serves as stabilization of the discoloration. Added, the average time for consumption of 1 cup of coffee is $15 \mathrm{~min}$, and among coffee drinkers, the average consumption is 3.2 cups per day. Therefore, 15 days of storage simulated consumption of the drink over 1 year.

Many quantitative analysis methods for measuring the surface roughness of dental materials have been used. In our study, surface roughness was evaluated in terms of an atomic force microscope since it is representative, going point by point with high resolution in nanometer scales covering a square area and visualizing a 3-dimensional image of the surface.

The results of this study revealed that ultrasonic instrumentation (U) has significantly changed the surface roughness of all the specimens. This could be explained by that the preferential removal of the weak matrix phase; thus leaving the harder filler particles protruding out from the surface which is in agreement with Hossam AE et al. [16] who proved that the higher the filler particle size, the higher will be the post-ultrasonic roughness.

Regarding the control (C) and manual plastic group (MP), a relatively smooth surface was the result. This might be due to that restorations visually appear to be smooth when a surface has a roughness of less than $1 \mu \mathrm{m}$ Ra. Also, hand instruments presented a significantly greater contact area between the instrument and the surface than that of ultrasonic instruments. A greater contact area could result in a smoother surface, masking the valleys formed on the surface due to the material substance removal.

On the other hand, the surface topography results revealed that after hand instrumentation, deep scratch lines were present while the ultrasonic instrumentation showed interrupted surfaces of multiple projections on the surface. These results coincide with Dahiya P et al. who proved that the deep scratch lines presented with hand instruments would possibly be attributed to the pathway of instrumentation and the microscopic roughness of the instrument's cutting edge i.e. would likely correspond to the curette tip.

The plastic instrument produced the least damage to the lava ultimate surface and, therefore, would appear to be the instrument of choice during a routine maintenance procedure. This is in accordance with Lee et al. [18] who stated that plastic instruments are designed to remove debris without scratching the material and should therefore not affect the ceramic material.

For color stability of tested samples, the perceptibility level set in this study was 1 $\Delta \mathrm{E}$ units, whereas the clinical acceptability 
level was set to $3.7 \Delta \mathrm{E}$ units as concluded by Khashayar et al. and Paravina et al. $[19,20]$. According to the $\Delta \mathrm{E}$ test results, the control (C), manual (M) and ultrasonic plastic groups (UP), and manual stainless steel (MSt) could be considered clinically acceptable.

Ferracane [21] reported that with the increase of surface roughness and degradation of the matrix/silane/filler, the material absorbs the water that penetrates the filler/ resin interface. This leads to hydrolysis of the silane, decreasing the filler particles retention. Hydrolytic degradation of this area affects light scattering, color perception, and enhances stain penetration and restoration discoloration.

Al Amri et al. [22] explained the decreased color stability of resin nanoceramics as that resin nanoceramic structure contains elements such as hydrophobic urethane dimethacrylate (UDMA), hydrophilic triethylene glycol dimethacrylate (TEGDMA), and bisphenol A-glycidyl methacrylate (Bis-GMA) that can increase the susceptibility of the color change. TEGDMA exhibits high water sorption which can lead the hydrophilic colorant to penetrate the resin matrix. Bis-GMA has the highest water sorption when compared with urethane dimethacrylate and TEGDMA. This possibly explains

Also, Lauvahutanon et al. [23] reported that lava ultimate had water sorption values higher than $30 \mu \mathrm{g} / \mathrm{mm}^{3}$. However, this high value was still within the acceptable range specified in ISO $4049\left(<40 \mu \mathrm{g} / \mathrm{mm}^{3}\right)$. This finding might be attributed to the zirconium oxide content of the filler, eventually resulting in reduced stability of the silane coupling agent.

Ultrasonic, which works on acoustic streaming and acoustic turbulence, leading to cavitation which increases the surface roughness of the material. This kind of surface irregularities increases the available surface area 2 to 3 times, which enhances the niche attachment and the growth of microorganisms leads to quicker bacterial accumulation. As surface irregularities increase, bacteria can be sheltered against shear forces, and consequently plaque accumulation occurs more easily than on smooth surfaces.

The findings of this study may show that stainless steel instruments could be used only for removing coarse deposits from resin nanoceramic restorations, but not for removing residual calculus and plaque, which should be done with a plastic scaler that causes no visible changes.

\section{Conflict of interest}

The authors have no proprietary, financial, or other personal interest of any nature or kind in any product, service, and/or company that is presented in this article.

\section{REFERENCES}

1. Padovani GC, Feitosa VP, Sauro S, Tay FR, Durán G, Paula AJ, et al. Advances in dental materials through nanotechnology: facts, perspectives and toxicological aspects. Trends Biotechnol. 2015;33(11):621-36.

2. Koller M, ArnetzI GV, Holly L, Arnetzl G. Lava ultimate resin nano ceramic for CAD/ CAM: customization case study. Int J Comput Dent. 2012;15(2):159-64.

3. Paravina RD, Ontiveros JC, Powers JM. Accelerated aging effects on color and translucency of bleaching-shade composites. J Esthet Restor Dent. 2004;16:117-26.

4. Lee SY, Lai YL, Morgano SM. Effects of ultrasonic scaling and periodontal curettage on surface roughness of porcelain. J Prosthet Dent. 1995;73 (3):227-32.

5. Scarano A, Piattelli M, Caputi S, Favero GA, Piattelli A. Bacterial adhesion on commercially pure titanium and zirconium oxide disks: an in vivo human study. J Periodontol. 2004;75(2):292-6. doi: 10.1902/ jop.2004.75.2.292.

6. Cross-Poline GN, Stach DJ, Newman SM. Effects of curette and ultrasonics on root surfaces. Am J Dent. 1995;8:131-3.

7. Bjornson EJ, Collins DE, Engler WO. Surface alteration of composite resins after curette, ultrasonic, and sonic instrumentation: an in vitro study. Quintessence Int. 1990;21(5):381-9.

8. Garnick JJ, Dent J. A scanning electron micrographical study of root surfaces and subgingival bacteria after hand and ultrasonic instrumentation. J Periodontol. 1989;60 (8):441-7.

9. Stout KJ, Blunt L. Three Dimensional Surface Topography: Instruments and measurement techniques of three-dimensional surface topography. Elsevier:2000.320 p. 
10. Awad D, Stawarczyk B, Liebermann A, llie N. Translucency of esthetic dental restorative $C A D / C A M$ materials and composite resins with respect to thickness and surface roughness. J Prosthet Dent. 2015 Jun;113(6):53440. doi:10.1016/.jprosdent.2014.12.003.

11. Bollen CM, Lambrechts P, Quirynen M. Comparison of surface roughness of oral hard materials to the threshold surface roughness for bacterial plaque retention: a review of the literature. Dent Mater. $1997 \mathrm{Jul} ; 13(4): 258$ 69. doi: 10.1016/s0109-5641(97)80038-3.

12. Seol HW, Heo SJ, Koak JY, Kim SK, Baek SH, Lee SY. Surface alterations of several dental materials by a novel ultrasonic scaler tip. J Oral Maxillofac Implants 2012; 27: 801-10.

13. Checketts MR, Turkyilmaz I, Asar NV. An investigation of the effect of scaling-induced surface roughness on bacterial adhesion in common fixed dental restorative materials. J Prosthet Dent. 2014 Nov;112(5):126570. doi: 10.1016/.jprosdent.2014.04.005.

14. Gibbons RJ, Nygaard M. Synthesis of insoluble dextran and its significance in the formation of gelatinous deposits by plaque-forming streptococci. Arch Oral Biol. 1968 Oct;13(10):1249-62. doi: 10.1016/0003-9969(68)900812.

15. Mourouzis P, Koulaouzidou EA, Vassiliadis L, Helvatjoglu-Antoniades M. Effects of sonic scaling on the surface roughness of restorative materials. J Oral Sci. 2009 Dec;51(4):607-14. doi: 10.2334/josnusd.51.607.

16. Hossam AE, Rafi AT, Ahmed AS, Sumanth PC. Surface topography of composite restorative materials following ultrasonic scaling and its Impact on bacterial plaque accumulation. An in-vitro SEM study. J Int Oral Health. 2013;5(3):13-9.
17. Dahiya P, Kamal R, Gupta R, Pandit N. Comparative evaluation of hand and power-driven instruments on root surface characteristics: a scanning electron microscopy study. Contemp Clin Dent. 2011;2(2):79-83.

18. Lee SY, Lai YL, Morgano SM. Effects of ultrasonic scaling and periodontal curettage on surface roughness of porcelain. J Prosthet Dent. 1995;73:227-32.

19. Khashayar G, Bain PA, Salari S, Dozic A, Kleverlaan CJ, Feilzer AJ. Perceptibility and acceptability thresholds for colour differences in dentistry. J Dent 2014;42(6) 637-44.

20. Paravina RD, Ontiveros JC, Powers JM. Accelerated aging effects on color and translucency of bleaching-shade composites. Esthet Restor Dent. 2004;16(2):117-26.

21. Ferracane JL. Hygroscopic and hydrolytic effects in dental polymer networks. Dent Mater. 2006;22(3):211-22.

22. Al Amri MD, Labban N, Alhijij S, Alamri H, Iskandar M, Platt JA. In vitro evaluation of translucency and color stability of cad/cam polymerinfiltrated ceramic materials after accelerated aging. J Prosthodont. 2020 Aug 19. doi: 10.1111/jopr.13239.

23. Lauvahutanon S, Shiozawa M, Takahashi H, Iwasaki N, Oki M, Finger WJ, Arksornnukit M. Discoloration of various CAD/CAM blocks after immersion in coffee. Restor Dent Endod. 2017 Feb;42(1):9-18. doi: 10.5395/ rde.2017.42.1.9.

\section{Engy Adel Ahmed Farag}

(Corresponding address)

The British University in Egypt, Fixed Prosthodontics, Faculty of Dentistry, Cairo, Egypt

Email: engy.farag@bue.edu.eg

Date submitted: 2020 0ct 25

Accept submission: 2021 Jan 13 